\title{
Reducing Risk from Lahar Hazard in Volcanic Catchment: Retarding Basin Site Assessment
}

\author{
Alzaena Ulya Rusdimi \\ Master on Planning and Management of Coastal Area and Watershed \\ Faculty of Geography, UGM \\ Yogyakarta, Indonesia \\ Coresponding email: ulyarusdimi@live.com \\ Junun Sartohadi \\ Department of Environmental Geography \\ Faculty of Geography, UGM \\ Yogyakarta, Indonesia \\ Su Ritohardoyo \\ Department of Regional Development \\ Faculty of Geography, UGM \\ Yogyakarta, Indonesia
}

\begin{abstract}
Indonesia poses as a country with the highest risk of natural disaster in Southeast Asia. With no less than 130 active volcanoes, volcanic eruption and lahars as the secondary hazard become inevitable. Major damage and casualties had been reported, thus encourage more proper mitigation measures to be applied. This study propose a retarding basin as a possible measure to decrease the magnitude of lahars by providing runoff control function as a reservoir containing a substantial volume of water at a predetermined conservation pool level. The aim of this study is to discuss the best location for retarding basin to retain stormwater during lahars and flash flood occurrence. A case study of Bladak catchment in Kelud volcano is taken. There are three main parameters used to determine the most proper retarding basin sites in this study, such as soils, slope, and land cover. The soils in Bladak catchment is classified in Hydrological Soil Group (HSG) as type A, while its topographic features and land cover are more varied. Taking into account river gradient of Bladak river and the positions of existing sabo dams cannot be separated from the spatial analysis of the topography and land cover to produce suitable areas for retarding basin installation. The retarding basin may pose as an effective mitigation measure for lahars and flash flood in volcanic slope since it also has functions of water quality and quantity control in addition to ecological function as a green area. By placing retarding basin in the secondary channels before they join into the primary channel, it is expected to reduce the magnitude of rapid accumulation streamflow following storm events.
\end{abstract}

Keywords-Retarding basin, lahar, flash flood, volcanic catchment

\section{INTRODUCTION}

Lahars and flash flood occur rapidly in a matter of few hours or even minutes from triggering events such as storm or failure of hydraulic infrastructure. The flood brings a sudden rise in water level in rivers and streams with large amounts of debris being transported. When the flood occurs in a volcanic upstream catchment following an eruption, the possibility of huge amount of pyroclastic materials in various of sizes being transported in a rapid rising streamflow is very high. As it flows downstream, it causes destruction to any activities near the riverbank such as settlement, mining or agricultural activities.

Indonesia, with no less than 130 active volcanoes, poses as a country with the highest risks of disasters, unexceptionally lahars and flash floods that stand as secondary hazards following a volcanic explosive eruption. Kelud Volcano is recognized as one of the most active volcanoes in Indonesia with the biggest fatalities caused by lahars, compared to other volcanoes in Indonesia (Pratomo, 2006). Initially, lahars flowing after an eruption in Kelud Volcano were caused by the failure of crater walls that the water spills from the crater lake. The casualties have raised awareness and efforts to drain the lake by constructing tunnel within the volcano had been done. By the effusive eruption in 2007, the lake was replaced by a huge lava dome that later destroyed by the explosive eruption in 2014. These major events brought alteration to the secondary hazards that follow the eruption. An intensive rainfall would form a viscous liquid with high density, carrying large stones and sediments as it flows down the river channels. Installation of sabo dams and sediment traps have been 
constructed along the river channels at Kelud volcanic slope. Sabo dam works as construction that control lahars following volcanic eruption by withstanding the sediments in several check dams gradually. The presence of sabo dams in river channels of Kelud volcanic slope had been reported able to reduce the impact of lahar flood, yet not effectively as it was submerged by the lahar flow following the eruption in 1990 .

A stormwater management of building retarding basin is proposed as a possible measure to decrease the magnitude of lahars. The retarding basin is a retention facility that provides a runoff control function as a reservoir containing a substantial volume of water at a predetermined conservation pool level. The retarding basin may hold stormwater runoff for short period of time before being released into the natural watercourse, or for considerable time for agricultural, consumptive, aesthetic or recreational purposes [3]. Streamflows can be slowly released downstream to minimize disruption and damage during both minor and major runoff (Mhonda, 2013). Determining the best sites for retarding basin is a part of important phases in designing and assessing retarding basins. Retarding basin works optimally when placed in a suitable locations that take into account the physical parameters of morphology [2], land cover and water table condition (Mhonda, 2013). This paper aims to discuss specifically on the proper location for retarding basin to work at its best in retaining stormwater during lahars and flash flood occurrence.

\section{METHOD}

\section{A. Materials and Tools}

Determining the best sites for retarding basin installation requires spatial analysis using Geographic Information System (GIS) and remote sensing. There are certain criteria needs to be taken into account. It is suggested to install a retarding basin in the upland to reduce discharge from upstream and flow velocity would be lower as it downland. Locations for the retarding basin needs to be in the waterways and placed along the secondary channel to prevent accumulated water in the joining point with the primary channel.

There are three main parameters being calculated in this study to find the best location for retarding basin, such as soils, slope, and land cover. To obtain such information, map of Rupa Bumi Indonesia scale 1 : 25.000 is needed to generate topography of the study area and high-resolution satellite imagery to provide detailed land cover information. Bing satellite imagery is used in this study to delineate the land cover classes.

Field measurement and laboratory analysis are necessary to assess the soil type of the study area. The determination of mapping unit is based on the concept that the combination between land use and soil types can represent the soil physical properties, particularly for sampling procedure (Simon, 2008). According to (Sartohadi et al., 2012), delineating soil units can be done through particular approach in accordance with the understanding on soil forming factors that can be identified consistently on the earth surface. Relief or landform poses as an important soil forming factor, as its components of slope angle and elevation affect the climatic condition of the area can be used to distinguish soil mapping unit. Thus, in this study the sampling location for soil properties analysis is based on the mapping unit generated from landform and land cover classes. A stratified random sampling under different landform and land cover is conducted to collect soil samples from the fields. A total of 10 sample points under different mapping unit were taken from field. Laboratory analysis is performed to identify the soil texture to determine its Hydrological Soil Group.

The obtained information of soil, slope and land cover of the study area are to be processed using a GIS tool, namely ArcGIS 10.1 and produce a suitability map for retarding basin location. Analysis through river gradient in order to place the retarding basin taking into account the existing sabo dam in the actual field is also done by conducting spatial analysis using ArcGIS 10.1.

\section{B. Study Area}

Bladak catchment is selected as the study site for this research. Bladak river is one of the tributaries that lies on the slopes of Kelud volcano. The catchment is astronomically located between $911366 \mathrm{mN}-9123058 \mathrm{mN}$ and $619099 \mathrm{mE}-$ $643515 \mathrm{mE}$. The end point of Bladak river branches into two streams, namely Termas Lama river and Termas Baru river. Bladak catchment approximately covers an area of $50,91 \mathrm{~km}^{2}$ and administratively is located as part of Blitar regency $(49,38$ $\mathrm{km}^{2}$ ) although there is a small part of the volcanic peak is included in Kediri regency $\left(1,987 \mathrm{~km}^{2}\right)$. The length of the main river reaches approximately $28,12 \mathrm{~km}$. Throughout the history of lahar floods in Kelud volcano, Bladak river had been reported as one of the channels that contributes the most in transporting lahars downstream. The front velocity of Bladak streams reaches up to $10,67 \mathrm{~m} / \mathrm{s}$ which is higher than Putih streams $(8,7 \mathrm{~m} / \mathrm{s})$ as both rivers have been reported transporting the largest volume of 1990 pyroclastic flow deposits and high alluvial terraces that also initiated debris flow hazards (Thouret, 1998). Figure 2.1 depicts the study area map showing the situation of Bladak catchment.

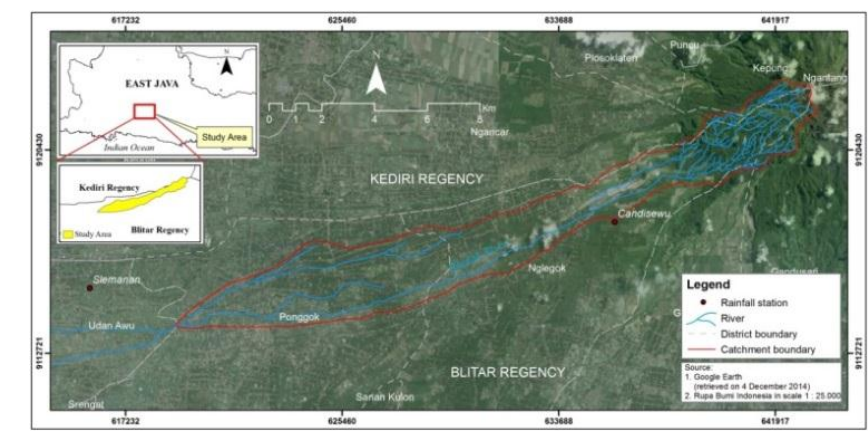

Fig. 1. Study area map of Bladak catchment

\section{FINDING AND DISCUSSION}

\section{A. Determining Suitable Areas for Retarding Basin}

There are various approaches in determining the proper location for retarding basin being discussed in many of stormwater management. In the case of Bladak catchment, the 
parameters accounted for retarding basin site locations are soil type, slope and land cover. As Bladak catchment is a relatively small catchment of the volcanic slope, the soil type of its entire area is classified as the soil type An of Hydrological Soil Group (HSG). Thus, slope and land cover classes are the remaining parameters being used to calculate the suitability of the retarding basin site locations.

The seasonal water table is also an important parameter to be considered as a construction of retarding basin should not go deeper than the seasonal groundwater in the proposed area. However, the groundwater table data is limited in this study, so that an assumption of a general rule is taken that the secondary channel in the upstream has lower water table compared to the primary channel. This consideration also underlies the determination of placing the retarding basin in the secondary channels upstream before the tributaries join to the primary channel. More specifically, the detail description of the parameters of determining the retarding basin is explained as follows.

\section{Soils}

Surface runoff occurs when precipitation rate exceeds the infiltration rate. The infiltration rate of soil is influenced by the subsurface permeability and surface intake rates. To indicate the minimum rate of infiltration obtained for bare soil after prolonged wetting, soils are classified into HSG with classes divided into A, B, C, and D.

The main consideration to soil surface condition for selecting retarding basin site is that there should be no excessive infiltration so that the wet pond will not dry out. Thus, the wet pond is not suggested to be constructed in areas where there would be no sufficient precipitation to maintain the pool or areas with highly permeable soils [1]. In this case, the soil type C and D in HSG are preferable to construct the retarding basin rather than the soil type $\mathrm{A}$ and $\mathrm{B}$, although the soil type A and B can still be the underlying soil with modification such as by applying impermeable liner ro reduce permeability.

Based on field sampling and result of laboratory analysis on the surface soil in Bladak catchment, the soil textures vary from sand in the upper part, loamy sand and sandy loam in the lower part. These textures are included as the soil type A according to HSG, which indicate that the soils in Bladak catchment possess high infiltration rate and water transmission. This condition is actually not sufficient to be the base of permanent pool in a retarding basin, since a highly permeable soil would affect the groundwater source by transferring water through percolation and drain the pond. In this case, a modification to the base of the pond such as installing impermeable layer is suggested. The distribution of soil texture in Bladak catchment is depicted in figure 3.1 below.

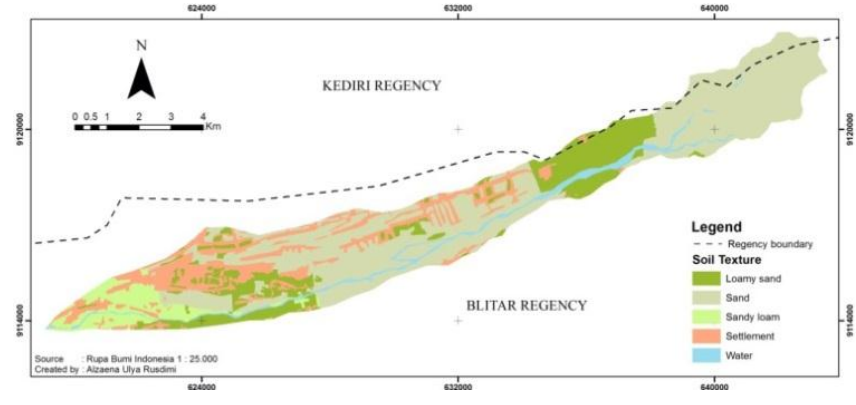

Fig. 2. Soil texture map of Bladak catchment

Slope

Slope and river valleys in the upstreams are geomorphological aspects determining the drainage systems as channels to transport lahars during storm events. The river flow pattern in volcanic landform comprises a radial centrifugal pattern that drives water to concentrate and accumulate in one point where tributaries meet. This point is possibly being the location where rising water level reach beyond the river banks and spill to its surroundings.

In a catchment context, linkages of upstream-downstream condition determines the hydrological processes. Locating a retarding basin to retain stormwater and reduce peak flow is highly recommended to be done in the upstream with slope not more than $15 \%$ and has a reasonable area for the size of detention pond [2]. Although the topography in the upstream is more likely to be ranging from steep to very steep, it is important to find a relatively flat location that would cover the proposed size of the retarding basin. It is necessary to have enough elevation drop from the pond inlet to the point outlet to ensure that the flow can move through the retarding basin system. The consideration also lies in the fact that relatively flat area would give a good maintenance access for heavy vehicles to enter the retarding basin sites. To score the suitability of areas based on the slope qualification, the areas with slope under $15 \%$ are given value of 1 which means the locations are suitable for retarding basin installment. On the other hand, the areas with slope above $15 \%$ are given value of 0 which means the areas are not suitable for retarding basin installment. The map of slope qualification of Bladak catchment is shown in figure 3.2 below.

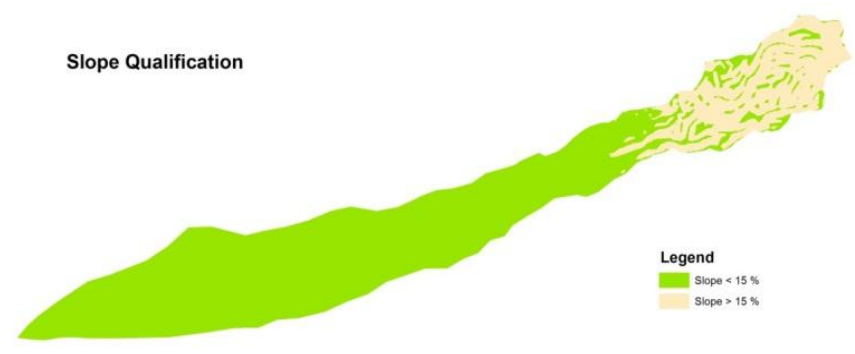

Fig. 3. Slope Qualification of Bladak catchment

As a typical catchment in volcanic upper slopes, Bladak catchment comprises an elongated shape with intermittent rivers that only flow throughout certain period of year. Most parts of its upstreams are steep areas that decrease gradually in 
the lower part. The tributaries are located in the upper part of the catchment and once they meet and flow in the primary channel, the topography began to grow flatter and forms as alluvial plain with slopes not more than $8 \%$.

\section{Land Cover}

Land cover plays major role in maintaining the overall health and function of a catchment as its variation influences the distribution of hydrologic parameter values, such as hydraulic conductivities (Hernandez et al., 2000). Land cover information such as vegetation coverage and impermeable areas are necessary to determine the surface runoff production after rainstorm event. Land cover map is generated from Bing satellite imagery as its high spatial resolution support the need for detailed land cover information.

Retarding basin location is proposed to be on vegetated areas, as vegetation has an important function in preventing the basin base scouring by high-speed flow velocity. It holds a key role in increasing infiltration rate, therefore preferably to remain undisturbed and only be removed if necessary for construction. Areas with vegetated land cover are considered to be suitable locations for retarding basin and given a value of 1. Conversely, settlements and bare lands are considered nonvegetated areas and are given a value of 0 which means not suitable for retarding basin locations. Figure 3.3 depicts the distribution of land cover qualification in Bladak catchment.

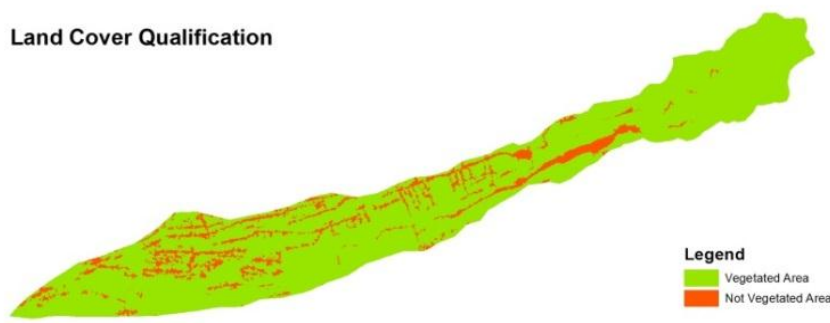

Fig. 4. Land cover qualification of Bladak catchment

Table 3.1 below expressed the scoring for the parameter qualifications such as slope and land cover in Bladak catchment. Both parameters are superimposed and scored to produce the suitability map for retarding basin sites, as shown in figure 3.4 .

TABLE 3-5 PARAMETER REQUIRED FOR SUITABLE RETARDING BASIN LOCATION

\begin{tabular}{clc}
\hline Parameter & \multicolumn{1}{c}{ Classes } & Score \\
\hline \multirow{2}{*}{ Slope } & $<15 \%$ & 1 \\
& $>15 \%$ & 0 \\
\hline & Bareland & 0 \\
& Bush & 1 \\
& Forest & 1 \\
& Grass & 1 \\
& Mix garden & 1 \\
& Moor & 1 \\
& Paddy field & 1 \\
& Settlement & 0 \\
\hline Source: Department of Environmental Protection of Pennsylvannia (2006); City of Indianapolis
\end{tabular}

(2011)

\section{Retarding Basin Position to Sabo Dams}

Several sabo dams had already been installed in Bladak catchment to reduce the flow velocity of lahar and restrain the sediments. This condition is taken into account in selecting the retarding basin sites, as the installation or both measures should not be overtopping. An analysis through river gradient is conducted to give an overview regarding the slope aspect along the river channel, as the retarding basin is proposed to be placed in the waterway. The river gradient represents the steepness of the river channel as a comparison between elevation with the river length.

\section{B. Proposing Retarding Basin Location}

The location for retarding basin is considered best to be selected in points where inundation is predicted to occur. Predicting inundation can be done by applying hydrological modeling with a hypothesis that the joining point of secondary channels to primary channel is the point where a sudden accumulation of rapid surface runoff occurs. It is speculated that the accumulation of water at those points will be retained by the retarding basins and reduce its discharge as it flows downstream afterward. To reassure the best performance of retarding basins, they are necessary to be located in the upstreams and should be as close as possible to the channels for easy water routing. The retarding basins are placed along the river channel with respectable distance. The assumption is that evenly small and distributed retarding basins along the predicted area of accumulated discharge is appropriate and convenient.

Based on the suitability map, two tributaries in Bladak catchment is selected. The selected river channels are situated in the upper part of the catchment before it joins into the main river. As the retarding basins are best to be placed in relatively flat areas, river gradient was taken into account in determining the location. Cross sections are analyzed and the points where slopes are less than $6 \%$ are selected as the proposed retarding basin sites. Thus, 7 retarding basin of 90000 to $152000 \mathrm{~m}^{2}$ are proposed to be distributed in the selected channels. The retarding basins also proposed to be installed in undeveloped areas in consideration that the ponds should not be overtopping with the existing settlements. However, access to the retarding basin sites need to be taken into account in a matter of future maintenance. The determination of the retarding basin site in considering of accessibility is done by manual interpretation Figure 3-5 shows the proposed retarding basin locations along Bladak secondary channels. 


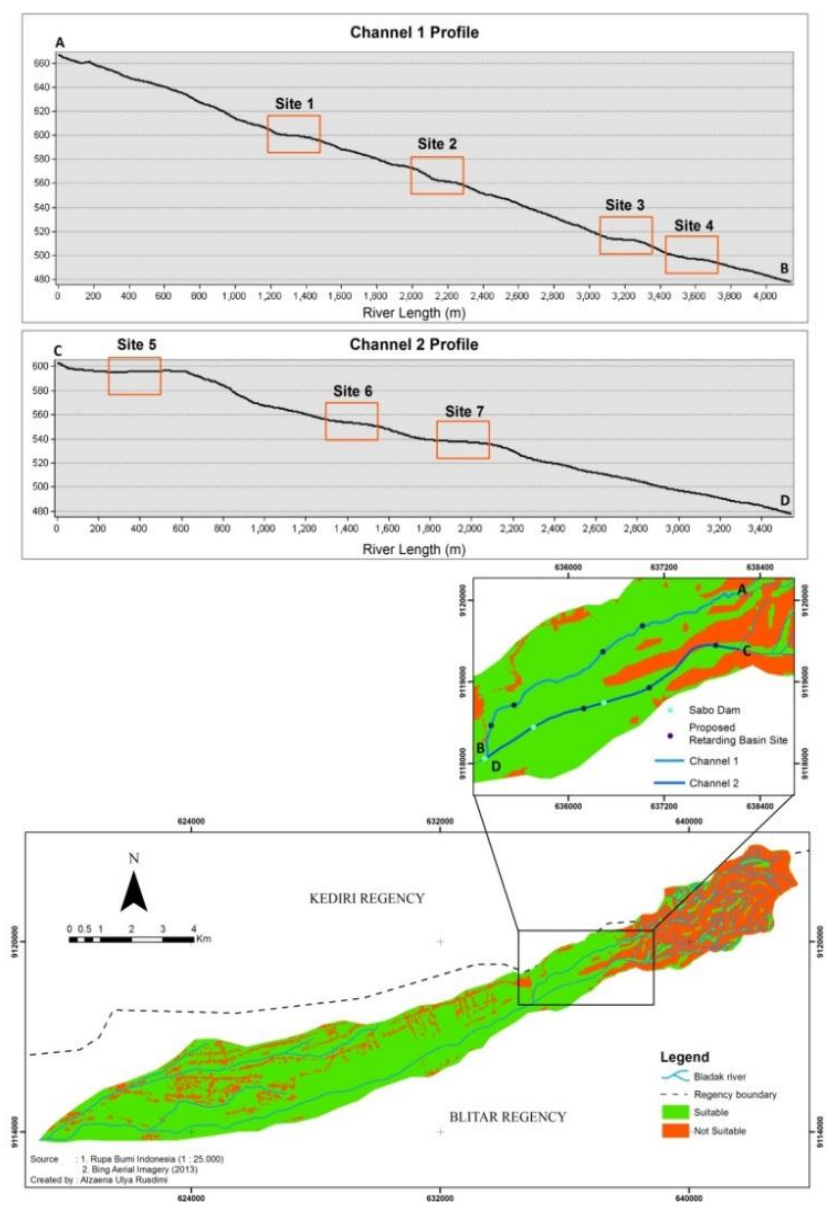

Fig. 5. Proposed Retarding Basin location in Bladak catchment

\section{CONCLUSIONS AND SUGGESTIONS}

Retarding basin stands as a structural measures to lahars and flash flood being proposed in this study to reduce the magnitude of rapid storm runoff. Based on a study case in Bladak catchment, retarding basin is possible to be installed in the upstreams even though the topography varies from steep to very steep, there are several flat points with enough area for the proposed retarding basin size. Taking into account river gradient of Bladak river and the positions of existing sabo dams cannot be separated from the spatial analysis of the topography and land cover to produce a suitable areas for retarding basin installation. The retarding basins are placed in the foot slope of Bladak catchment in consideration that it has a relatively low slope gradient and secondary channels can be found. The retarding basin is proposed to be installed in the secondary channels before they join into the primary channel so that the rapid accumulation of streamflow can be prevented.

The retarding basin may pose as an effective mitigation measure for lahars and flash flood in volcanic slope since it also has functions of water quality and quantity control in addition to the ecological function as a green area. However, a hazard risk reduction needs to be supported by another structural and non-structural measures with sustainable maintenance. Further study regarding the non-structural mitigation measure that include the social aspects is highly recommended as it is important to get understanding on the applicability and adaptability on implementing retarding basin withing the local communities.

\section{ACKNOWLEDGMENT}

The authors gratefully acknowledge that the work for this paper was carried out when Alzaena was completing her thesis in Master on Planning and Management of Coastal Area and Watershed, Faculty of Geography, Universitas Gadjah Mada. The research was carried out under the umbrella research of Kelud Team which is part of researches undertaken under the supervision of Prof. Dr.rer.nat. Junun Sartohadi, M.Sc at PhD level, specifically of Puspita Indra Wardhani, S.Pd., M.Sc. The authors also thank Puspita Indra W., Galih Aries S., Anastacia Neni, and Ekrar Winata for great assistance during field work.

\section{REFERENCES}

[1] EPA, 1999, "Storm Water Technology Fact Sheet: Wet Detention Ponds", EPA 832-F-99-048, Washington, D.C.: United States Environmental Protection Agency (EPA).

[2] EPA, 2006, "National Pollutant Discharge Elimination System (NPDES). Dry Detention Ponds", Retrieved 16/06/2013, from http://cfpub.epa.gov/npdes/stormwater/menuofbmps/index.cfm?action=f actsheet_results\&view $=$ specific $\&$ bmp $=67$.

[3] Colombo, A.G., Hevas, J., Arllam, A.L.V., 2002, "Guidelines on flash floods prevention and mitigation", Ipsra (Italy): NEIDES.

[4] Hernandez, M., Miller, S.N., Goodrich, D.C., Goff, B.F., Kepner, W.G., Edmonds, C.M. and Jones, K.B., 2000, "Modeling runoff response to land cover and rainfall spatial variability in semi-arid watersheds", Environmetal Monitoring and Assessment 64: 285-298, 2000.

[5] Mhonda, A., 2013, "Evaluating Flash Flood Risk Reduction Strategies in Built-up Envi-ronment in Kampala”, Netherland: University of Twente.

[6] Pratomo, I., 2006, "Klasifikasi gunung api aktif Indonesia, studi kasus dari beberapa letusan gunung api dalam sejarah", Jurnal Geologi Indonesia, Vol. 1 No. 4 Desember 2006: 209-227.

[7] Sartohadi, J. Jamulya and Dewi, N.I.S., 2012, "Pengantar Geografi Tanah", Pustaka Pelajar: Yogyakarta.

[8] Simon, R.D., 2008, "Combined Hydrological and Hydrodynamic Modeling for Flood Hazard Assessment; A Case Study of Upper Kaluganga Catchment, Ratnapura, Sri Lanka”, International Institute for Geo-Information Science and Earth Observation Enschede, Netherlands, $88 \mathrm{p}$.

[9] Thouret, J.C., Abdurachman, K.E., Bourdier, J.L. and Bronto, S., 1998, "Origin, characteristics and behaviour of lahars following the 1990 eruption of Kelud volcano, eastern Java (Indonesia)", Bull Volcanol (1998) 59: 460-480. 